\title{
Selective Extraction of Copper, Mercury, Silver and Palladium Ions from Water Using Hydrophobic Ionic Liquids
}

May 8, 2007

Nicolas Papaiconomou ${ }^{l, 2}$, Jong-Min Lee ${ }^{l, 2}$, Justin Salminen ${ }^{1,3}$, Moritz Von Stosch ${ }^{1,4}$ and John M. Prausnitz ${ }^{1,2 *}$

1 Department of Chemical Engineering, University of California, Berkeley, CA 947201462

2 Chemical Sciences Division, Lawrence Berkeley National Laboratory, Berkeley, CA 94720

3 Environmental Energy Technology Division, Lawrence Berkeley National Laboratory, Berkeley, CA 94720

$4 \quad$ Institut fuer Verfahrenstechnik, Technische Universitaet, Aachen, Germany

* Corresponding author. Email: prausnit@cchem.berkeley.edu

\begin{abstract}
Extraction of dilute metal ions from water was performed near room temperature with a variety of ionic liquids. Distribution coefficients are reported for fourteen metal ions extracted with ionic liquids containing cations 1-octyl-4-methylpyridinium [4MOPYR] $]^{+}$, 1-methyl-1octylpyrrolidinium $[\mathrm{MOPYRRO}]^{+}$or 1-methyl-1-octylpiperidinium $[\mathrm{MOPIP}]^{+}$, and anions tetrafluoroborate $\left[\mathrm{BF}_{4}\right]^{+}$, trifluoromethyl sulfonate $[\mathrm{TfO}]^{+}$or nonafluorobutyl sulfonate $[\mathrm{NfO}]^{+}$. Ionic liquids containing octylpyridinium cations are very good for extracting mercury
\end{abstract}


ions. However, other metal ions were not significantly extracted by any of these ionic liquids. Extractions were also performed with four new task-specific ionic liquids. Such liquids containing a disulfide functional group are efficient and selective for mercury and copper, whereas those containing a nitrile functional group are efficient and selective for silver and palladium.

\section{Introduction}

Wastewaters often contain offensive cations. ${ }^{1-8}$ Because of their high affinity for water, it is difficult to remove them using conventional solvents for liquid - liquid extraction. Hydrophobic ionic liquids may provide a useful extraction process. $^{9-28}$

Because the properties of ionic liquids are tunable, it may be possible to identify some ionic liquids that have low viscosity, very low solubility in water, and high affinity for selected metal ions. ${ }^{29-41}$

Previous reports show that ionic liquids containing imidazolium cations with alkyl chains and $\left[\mathrm{PF}_{6}\right]^{-}$anion are not useful for extraction of cations from water. ${ }^{9-15}$ Previous studies using ionic liquids containing $\left[\mathrm{PF}_{6}\right]^{-}$anion indicate that this anion decomposes to produce $\mathrm{HF}$ when contacted with water. ${ }^{42} \mathrm{~A}$ few recent reports have investigated the toxicity of ILs in water, suggesting that ionic liquids may be toxic for the environment. ${ }^{43-46}$ When co-extractants, such as crown-ethers, calixarene or other organic ligands, are added to ionic liquids, it is possible to attain high distribution coefficients for cations such as mercury, sodium or strontium. ${ }^{15-21}$ However, because ion-exchange may occur between the metal ion and the ionic-liquid's cation, the ionic liquid may decompose in water. ${ }^{22-25}$

Task-specific ionic liquids (TSIL), can extract cations without ion-exchange. ${ }^{26-28}$ TSILs are ionic liquids with functional groups appended to the cation. Some TSILs appear to be efficient 
for extraction with high selectivity for some metal ions such as mercury, cadmium, ${ }^{27,28}$ or actinides. $^{26}$

In this work, we investigate the ability of selected ionic liquids to extract offensive or valuable cations from water. We have studied the extraction properties of ten ionic liquids: 1octyl-3-methylimidazolium tetrafluoroborate $[\mathrm{OMIM}]^{+}\left[\mathrm{BF}_{4}\right]^{-}$, 1-octyl-3-methylpyridinium tetrafluoroborate $\quad[3 \mathrm{MOPYR}]^{+}\left[\mathrm{BF}_{4}\right]^{-}, \quad$ 1-octyl-4-methylpyridinium tetrafluoroborate $[4 \mathrm{MOPYR}]^{+}\left[\mathrm{BF}_{4}\right]^{-}$, 1-octyl-4-methylpyridinium trifluoromethylsulfonate $[4 \mathrm{MOPYR}]^{+}[\mathrm{TfO}]^{-}$, 1-octyl-4-methylpyridinium nonafluorobutylsulfonate $[4 \mathrm{MOPYR}]^{+}[\mathrm{NfO}]^{-}$and 1-octyl-4methylpyridinium bis(trifluoromethyl)sulfonylimide $[4 \mathrm{MOPYR}]^{+}\left[\mathrm{Tf}_{2} \mathrm{~N}\right]^{-}$, 1-butyronitrile-4methylpyridinium bis(trifluoromethyl)sulfonylimide $\quad[4 \mathrm{MPYRCN}]^{+}\left[\mathrm{Tf}_{2} \mathrm{~N}\right]^{-}, \quad$ 1-methyl-1butyronitrilepiperidinium bis(trifluoromethyl)sulfonylimide $[\mathrm{MPIPCN}]^{+}\left[\mathrm{Tf}_{2} \mathrm{~N}\right]^{-}, 1$-methyl-1[4,5-bis(methylsulfide)]pentylpiperidinium bis(trifluoromethyl)sulfonylimide $\left[4 \mathrm{MPIPS}_{2}\right]^{+}\left[\mathrm{Tf}_{2} \mathrm{~N}\right]^{-}, \quad$ and $\quad$ 1-methyl-1-[4,5-bis(methylsulfide)]pentylpyrrolidinium bis(trifluoromethyl)sulfonylimide $\left[4 \mathrm{MPYRROS}_{2}\right]^{+}\left[\mathrm{Tf}_{2} \mathrm{~N}\right]^{-}$. We have synthesized new TSILs: $[4 \mathrm{MPYRCN}]^{+}\left[\mathrm{Tf}_{2} \mathrm{~N}\right]^{-},[\mathrm{MPIPCN}]^{+}\left[\mathrm{Tf}_{2} \mathrm{~N}\right]^{-},\left[4 \mathrm{MPIPS}_{2}\right]^{+}\left[\mathrm{Tf}_{2} \mathrm{~N}\right]^{-}$and $[4 \mathrm{MPYRROS}]^{+}\left[\mathrm{Tf}_{2} \mathrm{~N}\right]^{-}$. Figure 1 shows structures and abbreviations of ionic liquids used here.

Except for [4MOPYR $]^{+}[\mathrm{NfO}]^{-}$, all ionic liquids studied here are liquid at room temperature. Some physical properties including solubility in water are given elsewhere. ${ }^{40}$ $[4 \mathrm{MOPYR}]^{+}[\mathrm{NfO}]^{-}$is solid at room temperature with melting point $78{ }^{\circ} \mathrm{C}$. However, when mixed with water, $[4 \mathrm{MOPYR}]^{+}[\mathrm{NfO}]^{-}$near $25^{\circ} \mathrm{C}$, we observe two liquid phases. The water content in $[4 \mathrm{MOPYR}]^{+}[\mathrm{NfO}]^{-}$decreases its melting point below room temperature. 


\section{Experimental:}

\section{Synthesis}

1-octyl-3-methylpyridinium tetrafluoroborate and 1-methyl-3-octylimidazolium tetrafluoroborate were used as received from Solvent Innovation. Synthesis of $[3 \mathrm{MOPYR}]^{+}\left[\mathrm{BF}_{4}\right]^{-}, \quad[4 \mathrm{MOPYR}]^{+}\left[\mathrm{BF}_{4}\right]^{-}, \quad[4 \mathrm{MOPYR}]^{+}\left[\mathrm{Tf}_{2} \mathrm{~N}\right]^{-}, \quad[4 \mathrm{MOPYR}]^{+}[\mathrm{TfO}]^{-}, \quad$ and $[4 \mathrm{MOPYR}]^{+}[\mathrm{TfO}]^{-}$was reported previously. ${ }^{40}$ Syntheses of our new TSILs are reported below.

The purity of each synthesized ionic liquids was checked with NMR and elemental analysis.

\section{$[4 \mathrm{MPYRCN}]^{+}\left[\mathrm{Tf}_{2} \mathrm{~N}\right]^{-}$}

$8.8 \mathrm{~g}\left(8.53 \cdot 10^{-2} \mathrm{~mol}\right)$ of 4-chlorobuthyronitrile, used as received from Aldrich (99 \% purity), was added drop-wise under nitrogen atmosphere, to a solution of $5 \mathrm{~g}\left(5.37 \cdot 10^{-1} \mathrm{~mol}\right)$ of 4 methylpyridine, used as received from Sigma (98\% purity), and $5 \mathrm{~cm}^{3}$ acetonitrile. After cooling to room temperature, the solvent was removed by rotary evaporation and the solid product was washed with ethyl acetate $\left(3 \times 100 \mathrm{~cm}^{3}\right)$ and filtered. Ethyl acetate was removed by rotary evaporation, and the resulting solid was set under vacuum for 12 h. $8.62 \mathrm{~g}\left(4.39 \cdot 10^{-2}\right.$ mol) of 1-butyronitrile-4-methylpyridinium chloride, [4MPYRCN $]^{+}[\mathrm{Cl}]^{-}$, was obtained as a gray solid (yield: $82 \%) .4 \mathrm{~g}\left(2.04 \cdot 10^{-2} \mathrm{~mol}\right)$ of [4MPYRCN $]^{+}[\mathrm{Cl}]^{-}$and $5.95 \mathrm{~g}\left(1.86 \cdot 10^{-2} \mathrm{~mol}\right)$ of potassium bis(trifluoromethylsulfonyl)imide, used as received from Wako Chemicals (99 $\%$ purity), were mixed in a flask containing $100 \mathrm{~cm}^{3}$ water for $24 \mathrm{~h}$. After filtering, removal of acetonitrile by rotary evaporation, washing with methylene chloride $\left(20 \mathrm{~cm}^{3}\right)$ and water $(3 \times$ $20 \mathrm{~cm}^{3}$ ), the product was set under high vacuum for $24 \mathrm{~h}$. The final product was $8.1 \mathrm{~g}$ of lightred liquid (yield: $90 \%$ ). 
${ }^{1} \mathrm{H} N M R\left(400 \mathrm{MHz}, \mathrm{CDCl}_{3}\right): \delta 2.163-2.367\left(2 \mathrm{H}, \mathrm{m}, \mathrm{CH}_{2}\right), 2.407-2.542\left(2 \mathrm{H}, \mathrm{m}, \mathrm{CH}_{2}\right)$, 2.571-2.650 (3H, d, $\left.\mathrm{CH}_{3}\right), 4.438-4.693\left(2 \mathrm{H}, \mathrm{m}, \mathrm{N}-\mathrm{CH}_{2}\right), 7.657-7.890\left(2 \mathrm{H}, t, \mathrm{CH}_{p y r-m}\right), 8.486-$ $8.919\left(2 \mathrm{H}, t, \mathrm{CH}_{\text {pyr-o }}\right)$.

(Found: C, 33.52; H, 3.13; N, 9.47. Calc. for $\mathrm{C}_{12} \mathrm{H}_{13} \mathrm{~N}_{3} \mathrm{O}_{4} \mathrm{~S}_{2} \mathrm{~F}_{6}: \mathrm{C}, 32.65 ; \mathrm{H}, 2.97 ; \mathrm{N}$, 9.52).

\section{$[\mathrm{MPIPCN}]^{+}\left[\mathrm{Tf}_{2} \mathrm{~N}\right]^{-}$}

$6.5 \mathrm{~g}\left(6.3 \cdot 10^{-2} \mathrm{~mol}\right)$ of 4-chlorobuthyronitrile, used as received from Aldrich (99 \% purity), was added drop wise, under nitrogen atmosphere, to a solution of $5 \mathrm{~g}\left(5.0410^{-2} \mathrm{~mol}\right)$ of 1 methylpiperidine, used as received from Sigma (98\% purity), and $5 \mathrm{~cm}^{3}$ acetonitrile. After cooling to room temperature, the solvent was removed by rotary evaporation and the solid product was washed with ethyl acetate $\left(3 \times 100 \mathrm{~cm}^{3}\right)$ and filtered. Ethyl acetate was removed by rotary evaporation, and the resulting solid was set under vacuum for $12 \mathrm{~h} .8 .62 \mathrm{~g}\left(4.2510^{-2}\right.$ mol) of 1-methyl-1-butyronitrilepiperidinium chloride, $[\mathrm{MPIPCN}]^{+}[\mathrm{Cl}]^{-}$, was obtained as a gray solid (yield: $84 \%) .4 \mathrm{~g}\left(1.97 \cdot 10^{-2} \mathrm{~mol}\right)$ of [MPIPCN $]^{+}[\mathrm{Cl}]^{-}$and $7.87 \mathrm{~g}\left(2.47 \cdot 10^{-2} \mathrm{~mol}\right)$ of potassium bis(trifluoromethylsulfonyl)imide, used as received from Wako Chemicals (99\% purity), were mixed in a flask containing $100 \mathrm{~cm}^{3}$ water for $24 \mathrm{~h}$. After filtering, removal of acetonitrile by rotary evaporation, washing with methylene chloride $\left(20 \mathrm{~cm}^{3}\right)$ and water $(3 \times$ $20 \mathrm{~cm}^{3}$ ), the product was set under high vacuum for $24 \mathrm{~h}$. The final product was $7.09 \mathrm{~g}$ of light-red liquid (yield: $80.4 \%$ ).

${ }^{1} H_{N M R}\left(400 \mathrm{MHz}\right.$, acetone-d $\left.{ }_{6}\right): \delta$ 1.736-1.816 (2H, $\left.m, \mathrm{CH}_{2}\right), 2.000-2.011\left(4 \mathrm{H}, \mathrm{m}, \mathrm{CH}_{2}\right)$, 2.284-2.363 (2H, $\left.m, \mathrm{CH}_{2}\right), 2.655-2.691\left(2 \mathrm{H}, t, \mathrm{CH}_{2}\right), 3.294-3.322\left(3 \mathrm{H}, d, \mathrm{~N}-\mathrm{CH}_{3}\right), 3.558-$ $3.605\left(2 \mathrm{H}, \mathrm{m}, \mathrm{N}-\mathrm{CH}_{2}\right), 3.615-6.805\left(4 \mathrm{H}, \mathrm{m}, \mathrm{N}-\mathrm{CH}_{2}\right)$.

(Found: C, 32.07; H, 4.30; N, 9.27. Calc. for $\mathrm{C}_{12} \mathrm{H}_{19} \mathrm{~N}_{3} \mathrm{O}_{4} \mathrm{~S}_{2} \mathrm{~F}_{6}: \mathrm{C}, 32.21 ; \mathrm{H}, 4.28 ; \mathrm{N}$, 9.39). 


\section{$[\mathrm{MPYRROS}]^{+}\left[\mathrm{Tf}_{2} \mathrm{~N}\right]^{-}$}

$4.29 \mathrm{~g}\left(2.9 \cdot 10^{-2} \mathrm{~mol}\right)$ of 5-bromopentene, used as received from Aldrich (99 \% purity), was added drop wise, under nitrogen atmosphere, to a solution of $2 \mathrm{~g}\left(2.35 \cdot 10^{-2} \mathrm{~mol}\right)$ of 1 methylpyrrolidine, used as received from Sigma (98\% purity), and $10 \mathrm{~cm}^{3}$ acetonitrile. After the same procedure described above, $5.08 \mathrm{~g}$ (yield: $68.5 \%$ ) of [MPPYRRO $]^{+}\left[\mathrm{Tf}_{2} \mathrm{~N}\right]^{-}$were obtained with a light-yellow color. K-10 montmorillonite, used as received from Fluka Chemical Company, was modified by adding $\mathrm{ZnCl}_{2}$ (2 mmol per gram of clay) to waterimpregnated clay. ${ }^{47}$ The catalyst was activated by heating at $150{ }^{\circ} \mathrm{C}$ for $24 \mathrm{~h}$ in a vacuum oven. Then, $5 \mathrm{~g}$ of the catalyst was mixed with $30 \mathrm{ml}$ of 1,2-dichloroethane and $15 \mathrm{mmol}$ of dimethyl disulfide. A solution of $10.4 \mathrm{mmol}$ of [MPPYRRO $]^{+}\left[\mathrm{Tf}_{2} \mathrm{~N}\right]^{-}$in $5 \mathrm{~cm}^{3}$ of 1,2dichloroethane was added drop-wise to the mixture. After filtering, removal of the solvents by rotary evaporation, the product was set under high vacuum for $24 \mathrm{~h}$. The final product was $3.79 \mathrm{~g}$ of a light-yellow liquid (yield: $69 \%$ ).

${ }^{1} H \mathrm{NMR}\left(400 \mathrm{MHz}\right.$, acetone- $\left.d_{6}\right): \delta 2.018-2.045\left(2 \mathrm{H}, \mathrm{m}, \mathrm{CH}_{2}\right), 2.064-2.085\left(3 \mathrm{H}, \mathrm{s}, \mathrm{S}-\mathrm{CH}_{3}\right)$, 2.092-2.112 (3H, s, $\left.\mathrm{S}-\mathrm{CH}_{3}\right), 2.113-2.200\left(2 \mathrm{H}, \mathrm{m}, \mathrm{CH}_{2}\right), 2.257-2.356\left(4 \mathrm{H}, \mathrm{s}, \mathrm{CH}_{2}\right), 2.634-2.706$ (H, $m, S-C H), 2.769-2.908\left(2 \mathrm{H}, \mathrm{m}, \mathrm{S}-\mathrm{CH}_{2}\right), 3.222-3.513\left(3 \mathrm{H}, \mathrm{m}, \mathrm{N}-\mathrm{CH}_{3}\right), 3.527-3.620(2 \mathrm{H}, \mathrm{m}$, $\left.\mathrm{N}-\mathrm{CH}_{2}\right), 3.836-3.857\left(4 \mathrm{H}, \mathrm{s}, \mathrm{CH}_{2}\right)$.

(Found: $\mathrm{C}, 32.92 ; \mathrm{H}, 4.82 ; \mathrm{N}$, 5.89. Calc. for $\mathrm{C}_{14} \mathrm{H}_{26} \mathrm{~N}_{2} \mathrm{O}_{4} \mathrm{~S}_{4} \mathrm{~F}_{6}: \mathrm{C}, 31.81 ; \mathrm{H}, 4.96$; $\mathrm{N}$, $5.30)$.

\section{$\left[\mathrm{MPIPS}_{2}\right]^{+}\left[\mathrm{Tf}_{2} \mathrm{~N}\right]^{-}$}

$7.51 \mathrm{~g}\left(5.04 \cdot 10^{-2} \mathrm{~mol}\right)$ of 5-bromopentene, used as received from Aldrich ( $99 \%$ purity), was added drop wise, under nitrogen atmosphere, to a solution of $4 \mathrm{~g}\left(4.03 \cdot 10^{-2} \mathrm{~mol}\right)$ of 1 methylpiperidine, used as received from Sigma (98\% purity), and $10 \mathrm{~cm}^{3}$ acetonitrile. After the same procedure described above, $8.11 \mathrm{~g}$ of $[\mathrm{MPPIP}]^{+}\left[\mathrm{Tf}_{2} \mathrm{~N}\right]^{-}$were obtained with a light- 
yellow color (yield: 76.8\%). K-10 montmorillonite, used as received from Fluka Chemical Company, was modified by adding $\mathrm{ZnCl}_{2}$ ( 2 mmol per gram of clay) using a wetimpregnation procedure ${ }^{47}$. The catalyst was activated by heating at $150{ }^{\circ} \mathrm{C}$ in a vacuum oven for 24 hours. $5 \mathrm{~g}$ of the catalyst was mixed with $30 \mathrm{ml}$ of 1,2-dichloroethane and $15 \mathrm{mmol}$ of dimethyl disulfide. A solution of $6.69 \mathrm{mmol}$ of [MPPIP $]^{+}\left[\mathrm{Tf}_{2} \mathrm{~N}\right]^{-}$in $5 \mathrm{ml}$ of 1,2-dichloroethane was added into the mixture. After filtering, removal of the solvents by rotary evaporation, the product was set under high vacuum for 24 h. $3.25 \mathrm{~g}$ (yield: $89.5 \%$ ) were obtained as a light yellow liquid.

${ }^{1} H$ NMR (400 MHz, acetone- $\left.d_{6}\right): \delta 1.661-1.741\left(2 \mathrm{H}, \mathrm{m}, \mathrm{CH}_{2}\right), 1.889-2.041\left(6 \mathrm{H}, \mathrm{m}, \mathrm{CH}_{2}\right)$, 2.062-2.079 (3H, s, S-CH3), 2.110-2.206 (2H, m, $\left.\mathrm{CH}_{2}\right), 2.622-2.694(\mathrm{H}, \mathrm{m}, \mathrm{S}-\mathrm{CH}), 2.769-$ $2.906\left(2 \mathrm{H}, \mathrm{m}, \mathrm{S}-\mathrm{CH}_{2}\right), 3.226-3.280\left(3 \mathrm{H}, \mathrm{t}, \mathrm{N}-\mathrm{CH}_{3}\right), 3.487-3.535\left(2 \mathrm{H}, \mathrm{m}, \mathrm{N}-\mathrm{CH}_{2}\right), 3.540-3.616$ $\left(4 \mathrm{H}, \mathrm{m}, \mathrm{N}-\mathrm{CH}_{2}\right)$.

(Found: C, 33.59; $\mathrm{H}, 5.07 ; \mathrm{N}$, 5.52. Calc. for $\mathrm{C}_{15} \mathrm{H}_{28} \mathrm{~N}_{2} \mathrm{O}_{4} \mathrm{~S}_{4} \mathrm{~F}_{6}$ : C, 33.2; H, 5.2; $\mathrm{N}, 5.16$ ).

\section{$\underline{\text { Extraction }}$}

Extraction of metal ions in water was performed as follows:

First, a stock solution was prepared. Chloride metal salts were added to $500 \mathrm{~cm}^{3}$ of pure water. Concentration of metal ions in water ranged from 50 to $500 \mathrm{mg} / \mathrm{kg}$.

A sample of $20 \mathrm{~g}$ of stock solution, was then taken and saturated with an ionic liquid. When the solubility in water of an ionic liquid is known, an amount of ionic liquid, slightly higher than the one corresponding to the solubility in water of the IL, was added to the solution. When the solubility in water of the ionic liquid was unknown, $1 \%$ by weight of 
ionic liquid was added to $20 \mathrm{~g}$ of stock solution. The resulting stock solution saturated in ionic liquid is referred to as the initial solution.

When the water content of an ionic liquid is high, an ionic liquid phase saturated in water is prepared. Water is added to an ionic liquid until two phases appear.

The extraction experiments were carried out by mixing a sample of initial solution (typically $5 \mathrm{~g}$ ) with an ionic liquid. After the two phases are placed on a shaker for $48 \mathrm{~h}$, they were centrifuged at $2500 \mathrm{RPM}$ for 20 minutes. The two phases remain in contact for another $24 \mathrm{~h}$ to reach equilibrium.

$3 \mathrm{~g}$ of the upper aqueous phase, referred to as final solution, was then removed for analysis. Initial and final solutions are analyzed by inductively-coupled-plasma-optical-emission spectroscopy (ICP - OES). Distribution coefficients are calculated from:

$$
D=\frac{C_{i n}-C_{f i n}}{C_{f i n}} \frac{m_{w}}{m_{I L}}
$$

where $C_{\text {in }}$ is the concentration in $\mathrm{mg} / \mathrm{kg}$ of metal $\mathrm{M}$ in the initial aqueous solution and $C_{f i n}$ is the concentration in $\mathrm{mg} / \mathrm{kg}$ of metal $\mathrm{M}$ in the final aqueous solution; $m_{w}$ and $m_{I L}$ correspond to the mass of water and ionic liquid, respectively.

It was not possible to measure distribution coefficients below 0.05 . For very high distribution coefficients, we report $D=1000$.

Using $[\mathrm{OMIM}]^{+}\left[\mathrm{BF}_{4}\right]^{-},[3 \mathrm{MOPYR}]^{+}\left[\mathrm{BF}_{4}\right]^{-}$or $[4 \mathrm{MOPYR}]^{+}\left[\mathrm{BF}_{4}\right]^{-}$, extraction was studied for seven metal ions. For all other ionic liquids, fifteen metal ions were studied. Table 1 shows the ILs and metal ions used.

Experimental results, done in duplicates, agree within $5 \%$.

\section{Results and discussion}


Distribution coefficients of metal ions obtained with classical ionic liquids are discussed first followed by those obtained with task-specific ionic liquids.

All ionic liquids form two liquid phases when contacted with water. [4MOPYR $]^{+}[\mathrm{NfO}]^{-}$and $[4 \mathrm{MOPYR}]^{+}\left[\mathrm{Tf}_{2} \mathrm{~N}\right]^{-}$have solubilities in water of 0.065 and $0.022 \mathrm{wt} \%$, respectively. ${ }^{20}$ All other generic ionic liquids (not task-specific ionic liquids) exhibit relatively high solubilities in water, typically above $1 \mathrm{wt}-\%$ in water. These solubilities are too high for industrial application.

Tables 2 to 6 show distribution coefficients for metal ions in water.

\section{Extraction with ionic liquids containing $/ B F_{4} L^{=}$}

Table 2 shows distribution coefficients for metal ions extracted from water with $[\mathrm{OMIM}]^{+}\left[\mathrm{BF}_{4}\right]^{-},[3 \mathrm{MOPYR}]^{+}\left[\mathrm{BF}_{4}\right]^{-}$and $[4 \mathrm{MOPYR}]^{+}\left[\mathrm{BF}_{4}\right]^{-}$.

Except for mercury, distribution coefficients are low. D is 25 for mercury with $[\mathrm{OMIM}]^{+}\left[\mathrm{BF}_{4}\right]^{-}$. With $[3 \mathrm{MOPYR}]^{+}\left[\mathrm{BF}_{4}\right]^{-}$or $[4 \mathrm{MOPYR}]^{+}\left[\mathrm{BF}_{4}\right]^{-}$; D for mercury is at least two orders of magnitude higher than those for other cations. The cation ring of the ionic liquid containing $[3 \mathrm{MOPYR}]^{+}$or $[4 \mathrm{MOPYR}]^{+}$has a significant influence on the extraction of $\mathrm{Hg}^{2+}$ That is known to form stable complexes $\mathrm{HgCl}_{2}, \mathrm{HgCl}_{3}{ }^{-}$or $\mathrm{HgCl}_{4}{ }^{2-}$, which may interact with $[3 \mathrm{MOPYR}]^{+}$or $[4 \mathrm{MOPYR}]^{+}$cations.

To investigate if ion-exchange occurs during extraction, single extraction was studied for mercury chloride in water with $[3 \mathrm{MOPYR}]^{+}\left[\mathrm{BF}_{4}\right]^{-}$or $[4 \mathrm{MOPYR}]^{+}\left[\mathrm{BF}_{4}\right]^{-}$.

When a cation exchange occurs, the metal ion in the aqueous phase is exchanged with a cation of the ionic liquid. The metal ion is then extracted in the ionic liquid, while the IL 
cation moves to the aqueous phase. (When anion-exchange occurs, the IL anion is exchanged with the metal counter ion.)

If cation exchange occurs when $[3 \mathrm{MOPYR}]^{+}\left[\mathrm{BF}_{4}\right]^{-}$or $[\mathrm{OMIM}]^{+}\left[\mathrm{BF}_{4}\right]^{-}$is used for mercury extraction, an increased amount of $[3 \mathrm{MOPYR}]^{+}$or $[\mathrm{OMIM}]^{+}$is expected to be found in the aqueous phase. If anion exchange occurs, we expect to find more $\left[\mathrm{BF}_{4}\right]^{-}$anion in the aqueous phase after extraction. ICP-OES data give the emission intensities of carbon and boron, in the aqueous phase before and after extraction experiment gives insight into the amount of IL cation (containing carbon atoms) and anion (containing boron atom), respectively, present into the aqueous phase.

To make sure the increase in carbon or boron is significant enough to be observed, we prepared highly concentrated solutions of mercury in water. The weight percent mercury in water was approximately 0.05 , one third of the water solubility of ionic liquids containing $\left[\mathrm{BF}_{4}\right]^{-}$anion: (1.59 and 1.65$)$ wt- $\%$ for $[\mathrm{OMIM}]^{+}\left[\mathrm{BF}_{4}\right]^{-}$and $[3 \mathrm{MOPYR}]^{+}\left[\mathrm{BF}_{4}\right]^{-}$, respectively. ${ }^{39,40}$

Following single extraction of mercury in water with either $[3 \mathrm{MOPYR}]^{+}\left[\mathrm{BF}_{4}\right]^{-}$or $[\mathrm{OMIM}]^{+}\left[\mathrm{BF}_{4}\right]^{-}$, there was no increase of boron or carbon in the aqueous phase Therefore, no ion exchange occurs during the extraction of mercury from water with $[3 \mathrm{MOPYR}]^{+}\left[\mathrm{BF}_{4}\right]^{-}$or $[4 \mathrm{MOPYR}]^{+}\left[\mathrm{BF}_{4}\right]^{-}$

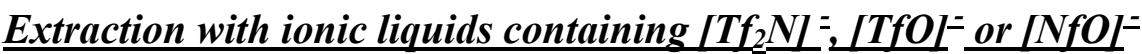

Table 3 shows distribution coefficients for 4 cations (i.e., $\mathrm{Na}^{+}, \mathrm{Cu}^{2+}, \mathrm{Tl}^{+}$and $\mathrm{Hg}^{2+}$ ) in water extracted with $[4 \mathrm{MOPYR}]^{+}\left[\mathrm{Tf}_{2} \mathrm{~N}\right]^{-},[4 \mathrm{MOPYR}]^{+}[\mathrm{TfO}]^{-}$or $[4 \mathrm{MOPYR}]^{+}[\mathrm{NfO}]^{-}$. For all other metal ions (see Table 1), no extraction was observed with $[4 \mathrm{MOPYR}]^{+}\left[\mathrm{Tf}_{2} \mathrm{~N}\right]^{-}$, $[4 \mathrm{MOPYR}]^{+}[\mathrm{TfO}]^{-}$or $[4 \mathrm{MOPYR}]^{+}[\mathrm{NfO}]^{-}$. 
Extracting properties of all ionic liquids are low. Ionic liquids containing $\left[\mathrm{Tf}_{2} \mathrm{~N}\right]^{-}$anions do not extract any cation.

For $[4 \mathrm{MOPYR}]^{+}[\mathrm{TfO}]^{-}$and $[4 \mathrm{MOPYR}]^{+}[\mathrm{NfO}]^{-}$, extraction results are similar to those for $[4 \mathrm{MOPYR}]^{+}\left[\mathrm{BF}_{4}\right]^{-}$. Only mercury is well extracted with these pyridinium ionic liquids.

Following extraction, we observed an increase in sulfur (from the anion of the ionic liquid) or carbon (from cation and anion) in the aqueous phase.

Considering the high solubility in water for $[4 \mathrm{MOPYR}]^{+}[\mathrm{TfO}]^{-}(1.59 \mathrm{wt}-\%)$, nearly as large as that for $[4 \mathrm{MOPYR}]^{+}\left[\mathrm{BF}_{4}\right]^{-}(1.65 \mathrm{wt}-\%)$, these two ionic liquids are not suitable for extraction. However, because $[4 \mathrm{MOPYR}]^{+}[\mathrm{NfO}]^{-}$exhibits a solubility of $0.065 \mathrm{wt}-\%$, it may be a good extracting agent for mercury.

\section{$\underline{\text { Extraction with task-specific ionic liquids }}$}

Following the work of Rodgers et al. and others, ${ }^{27,28,48}$ we have synthesized some taskspecific ionic liquids for extraction of specific metal ions. To study the effect of both the cation ring and the functional group appended to that ring, we synthesized two types of taskspecific ionic liquids.

First, we studied ionic liquids containing a functional nitrile group appended to either a pyridinium or a piperidinium cation. Second, we studied ionic liquids containing a functional disulfide group appended to a piperidinium or a pyrrolidinium cation. Figure 1 shows structures and abbreviations. 


\section{TSILs containing a nitrile group}

Table 4 shows results for competitive extraction of 12 metal ions with [4MPYRCN] $]^{+}\left[\mathrm{Tf}_{2} \mathrm{~N}\right]^{-}$ or $[\mathrm{MPIPCN}]^{+}\left[\mathrm{Tf}_{2} \mathrm{~N}\right]^{-}$. Table 5 shows results for the single extractions of aqueous silver nitrate or palladium chloride.

Synthesis and application of a similar TSIL containing a pyridinium ring and a nitrile group are described elsewhere. ${ }^{48}$ In water, this TSIL was reported to form a stable complex with palladium cation.

In our work, TSILs with a nitrile functional group are expected to extract ions like nickel or zinc. Following a previous report, they are also expected to extract silver or palladium. ${ }^{48}$ Regrettable, nickel and zinc ions are not efficiently extracted by the two TSILs used here. However, silver and palladium are completely removed from water.

For ionic liquids containing a nitrile group, results depend significantly on the cation. Except for silver and palladium, distribution coefficients for all metal ions obtained with $[4 \mathrm{MPYRCN}]^{+}\left[\mathrm{Tf}_{2} \mathrm{~N}\right]^{-}$are one order or magnitude higher than those obtained with $[\mathrm{MPIPCN}]^{+}\left[\mathrm{Tf}_{2} \mathrm{~N}\right]^{-}$. Compared to distribution coefficients obtained with $[4 \mathrm{MOPYR}]^{+}\left[\mathrm{Tf}_{2} \mathrm{~N}\right]^{-}$, the presence of a nitrile functional group in $[4 \mathrm{MPYRCN}]^{+}\left[\mathrm{Tf}_{2} \mathrm{~N}\right]^{-}$significantly improves extraction. For example, the distribution coefficient for mercury is only 0.22 in $[4 \mathrm{MOPYR}]^{+}\left[\mathrm{Tf}_{2} \mathrm{~N}\right]^{-}$but 1.35 in $[4 \mathrm{MPYRCN}]^{+}\left[\mathrm{Tf}_{2} \mathrm{~N}\right]^{-}$.

All other metal ions are modestly extracted with $[4 \mathrm{MPYRCN}]^{+}\left[\mathrm{Tf}_{2} \mathrm{~N}\right]^{-}$. Three metal ions have a distribution coefficient above unity: $\mathrm{Tl}^{+}(1.69), \mathrm{Na}^{+}(1.26)$ and $\mathrm{Hg}^{2+}$ (1.35). All others have distribution coefficients between 0.30 and 1.00 .

With $[\mathrm{MPIPCN}]^{+}\left[\mathrm{Tf}_{2} \mathrm{~N}\right]^{-}$, results are quite different. Despite the presence of a nitrile group, most distribution coefficients are below unity. 
Surprisingly, changing the cation ring appears to have an important effect on the extraction properties of TSILs containing a nitrile group on the IL's cation.

Both $[4 \mathrm{MPYRCN}]^{+}\left[\mathrm{Tf}_{2} \mathrm{~N}\right]^{-}$and $[\mathrm{MPIPCN}]^{+}\left[\mathrm{Tf}_{2} \mathrm{~N}\right]^{-}$appear to be very good and selective extracting agents for palladium and silver. Whereas all distribution coefficients shown in Table 4 are near or below 1, we observe high distribution coefficients for silver: 41 and 8.1 with $[4 \mathrm{MPYRCN}]^{+}\left[\mathrm{Tf}_{2} \mathrm{~N}\right]^{-}$and $[\mathrm{MPIPCN}]^{+}\left[\mathrm{Tf}_{2} \mathrm{~N}\right]^{-}$, respectively. Here again, the presence of a piperidinium cation reduces the extracting properties of the TSIL. D for palladium shows a maximum at 1000 .

When the initial solution of $200 \mathrm{ppm}$ of palladium chloride was presaturated with $[4 \mathrm{MPYRCN}]^{+}\left[\mathrm{Tf}_{2} \mathrm{~N}\right]^{-}$or $[\mathrm{MPIPCN}]^{+}\left[\mathrm{Tf}_{2} \mathrm{~N}\right]^{-}$, analysis of the initial solution by ICP-OES shows that almost all palladium was removed from the aqueous phase. It appears, therefore, that palladium ion forms a complex with the TSIL. ${ }^{48}$

\section{TSILs containing a disulfide group}

To study an ionic liquid with specific attraction for mercury, we synthesized a new TSIL containing a disulfide group.

Because mercury and sulfur are known to interact strongly, we expect mercury ion to bind strongly with this functional group. Considering the structure of the functional group, it is also expected to be selective for ions of a certain size.

To investigate the effect of the cation ring on the distribution coefficients of metal ions, two cations, piperidinium and pyrrolidinium, were used here. Figure 1 shows structures and abbreviations 
Table 6 shows results for competitive extraction with [MPYRROS2] $]^{+}\left[\mathrm{Tf}_{2} \mathrm{~N}\right]^{-}$and $[\mathrm{MPIP} 2]^{+}\left[\mathrm{Tf}_{2} \mathrm{~N}\right]^{-}$.

As expected, mercury is completely extracted with both TSILs synthesized here. The selectivity towards mercury is very high; the distribution coefficient for cadmium is 0.17 and lead is not extracted at all.

$\mathrm{Cu}^{2+}$ is also completely removed from water. The selectivity for $\mathrm{Cu}^{2+}$ is also high because neither $\mathrm{Ni}^{2+}$ nor $\mathrm{Zn}^{2+}$ is extracted.

As for nitrile-functionalized ionic liquids, the cation ring has a significant influence on the extraction of metal ions. While mercury and copper are equally well extracted with $[\mathrm{MPYRROS}]^{+}\left[\mathrm{Tf}_{2} \mathrm{~N}\right]^{-}$or $\left[\mathrm{MPIPS}_{2}\right]^{+}\left[\mathrm{Tf}_{2} \mathrm{~N}\right]^{-}$, other metal ions are somewhat extracted with $[\mathrm{MPYRROS}]^{+}\left[\mathrm{Tf}_{2} \mathrm{~N}\right]^{-}$but not at all with $[\mathrm{MPIPS} 2]^{+}\left[\mathrm{Tf}_{2} \mathrm{~N}\right]^{-}$.

As shown in Table 6, $\left[\mathrm{MPIPS}_{2}\right]^{+}\left[\mathrm{Tf}_{2} \mathrm{~N}\right]^{-}$extracts only mercury, copper, and tin $(D=70.5)$. All other metals are not extracted at all. For $\left[\mathrm{MPYRROS}_{2}\right]^{+}\left[\mathrm{Tf}_{2} \mathrm{~N}\right]^{-}$, however, low distribution coefficients (about 0.5 ) are obtained for most metals. Iron, zinc, cadmium and tin are more extracted with distribution coefficients $2.89,0.89,0.97$ and 4.35 , respectively.

Once again, the ionic liquid containing piperidinium is less efficient than that containing pyrrolidinium.

\section{Conclusion}

Ten ionic liquids were studied for metal-ion extraction from water. All ionic liquids (except $[\mathrm{OMIM}]^{-}\left[\mathrm{BF}_{4}\right]^{-}$) were newly synthesized for this work. Except for mercury, ionic liquids containing pyridinium cations without any functional group exhibit poor extracting properties; similar results were reported for imidazolium homologues ${ }^{12}$. However, extraction of mercury is very high with ionic liquids containing pyridinium cations. 
Task-specific ionic liquids containing a nitrile functional group appear to be a good and selective extracting agent for silver or palladium ions. Low distribution coefficients are obtained for all other ions studied here. The influence of the cation ring of the ionic liquid seems to have a significant effect on the extraction properties of TSILs. Compared to pyridinium ions, piperidinium ions reduce the extracting properties of a TSIL containing a nitrile functional group.

With a TSIL containing a disulfide group, mercury and copper were totally extracted from water. Once again, extraction of other metal ions is reduced when a piperidinium cation is used instead of a pyrrolidinium ion.

It appears that an ionic liquid containing piperidinium cations exhibits reduced extracting properties relative to other ionic liquids containing pyrrolidinium or pyridinium cations.

As observed by others, extraction of metal ions can be achieved by using TSILs with specific functional groups. However, in addition to the functional groups, the cation ring as well as the anion of an ionic liquid also has an influence on distribution coefficients. Pyridinium or pyrrolidinium cations enhance low distribution coefficients as compared to imidazolium or piperidinium cations. Using $[\mathrm{TfO}]^{-}$or $[\mathrm{NfO}]^{-}$instead of $\left[\mathrm{Tf}_{2} \mathrm{~N}\right]^{-}$anions also leads to enhanced extraction for mercury.

\section{Acknowledgements}

For financial support, the authors are grateful to TEKES and to the Office of Basic Sciences of the US Dept. of Energy. 


\section{REFERENCES}

(1) Swarup, D.; Patra, R. C. Environmental pollution and its impact on domestic animals and wildlife. Indian J. Animal Sci. 2005, 75, 231.

(2) Kenntner, N.; Krone, O.; Altenkamp, R.; Tataruch, F. Environmental contaminants in liver and kidney of free-ranging northern goshawks (Accipiter gentilis) from three regions of Germany. Arch. Environ. Contamin. Toxicol. 2003, 45, 128.

(3) Woolf, A. D.; Woolf, N. T. Childhood lead poisoning in 2 families associated with spices used in food preparation. Pediatrics 2005, 116, E314.

(6) Auger, N.; Kofman, O.; Kosatsky, T.; Armstrong, B. Low-level methylmercury exposure as a risk factor for neurologic abnormalities in adults. Neurotoxicol. 2005, 26, 149 .

(7) Zahir, F.; Rizwi, S. J.; Haq, S. K.; Khan, R. H. Low dose mercury toxicity and human health. Environmen. Toxicol. Pharmacol. 2005, 20, 351.

(8) Gochfeld, M. Cases of mercury exposure, bioavailability, and absorption. Ecotoxicol. Environmen. Safety 2003, 56, 174.

(9) Dietz, M. L. Ionic liquids as extraction solvents: Where do we stand? Sep. Sci. Technol. 2006, 41, 2047.

(10) Stepinski, D. C.; Young, B. A.; Jensen, M. P.; Rickert, P. G.; Dzielawa, J. A.; Dilger, A. A.; Rausch, D. J.; Dietz, M. L. Application of ionic liquids in actinide and fission product separations: Progress and prospects. In Separations for the Nuclear Fuel Cycle in the 21st Century, Vol. 933, pp 233-247, 2006. 
(11) Vidal, S. T. M.; Correia, M. J. N.; Marques, M. M.; Ismael, M. R.; Reis, M. T. A. Studies on the use of ionic liquids as potential extractants of phenolic compounds and metal ions. Sep. Sci. Technol. 2004, 39, 2155.

(12) Visser, A. E.; Swatloski, R. P.; Griffin, S. T.; Hartman, D. H.; Rogers, R. D. Liquid/liquid extraction of metal ions in room temperature ionic liquids. Sep. Sci. Technol. 2001, 36, 785 .

(13) Wei, G. T.; Chen, J. C.; Yang, Z. S. Studies on liquid/liquid extraction of copper ion with room temperature ionic liquid. J. Chinese Chem. Soc. 2003, 50, 1123.

(14) Wei, G. T.; Yang, Z. S.; Chen, C. J. Room temperature ionic liquid as a novel medium for liquid/liquid extraction of metal ions. Anal. Chim. Acta 2003, 488, 183.

(15) Bartsch, R. A.; Chun, S.; Dzyuba, S. V. Ionic liquids as novel diluents for solvent extraction of metal salts by crown ethers. In Industrial Applications Ionic Liquids, Rogers, R. D.; Seddon, K. R., Eds., ACS Symp. Ser. 818, pp 58-68, 2002.

(16) Bartsch, R. A.; Surowiec, K.; Li, S. F.; Dzyuba, S. V. Metal ion extraction by crown ethers in ionic liquids. Abstracts of Papers of the Am. Chem. Soc. 2003, 226, U625.

(17) Dai, S.; Ju, Y. H.; Barnes, C. E. Solvent extraction of strontium nitrate by a crown ether using room-temperature ionic liquids. J. Chem. Soc.-Dalton Transac. 1999, 8, 1201.

(18) Luo, H. M. Solvent extraction of alkali and alkaline earth metal salts by room temperature ionic liquids containing crown ethers. Abstracts of Papers of the Am. Chem. Soc. 2003, 225, U977. 
(19) Luo, H. M.; Dai, S.; Bonnesen, P. V. Solvent extraction of $\mathrm{Sr}^{2+}$ and $\mathrm{Cs}^{+}$based on room-temperature ionic liquids containing monoaza-substituted crown ethers. Anal. Chem. 2004, 76, 2773.

(20) Luo, H. M.; Dai, S.; Bonnesen, P. V.; Buchanan, A. C.; Holbrey, J. D.; Bridges, N. J.; Rogers, R. D. Extraction of cesium ions from aqueous solutions using calix[4]arene-bis(tertoctylbenzo-crown-6) in ionic liquids. Anal. Chem. 2004, 76, 3078.

(21) Giridhar, P.; Venkatesan, K. A.; Srinivasan, T. G.; Rao, P. R. V. Extraction of fission palladium by Aliquat 336 and electrochemical studies on direct recovery from ionic liquid phase. Hydromet. 2006, 81, 30 .

(22) Dietz, M. L.; Dzielawa, J. A.; Jensen, M. P.; Beitz, J. V.; Borkowski, M., Mechanisms of metal ion transfer into ionic liquids and their implications for the application of ionic liquids as extraction solvents. In Ionic Liquids IIIB: Fundamentals, Progress, Challenges, and Opportunities: Transformations and Processes, ACS Symp. Ser., 902, 2005.

(23) Dietz, M. L.; Stepinski, D. C. A ternary mechanism for the facilitated transfer of metal ions into room-temperature ionic liquids (RTILs): implications for the "greenness" of RTILs as extraction solvents. Green Chem. 2005, 7, 747.

(24) Jensen, M. P.; Neuefeind, J.; Beitz, J. V.; Skanthakumar, S.; Soderholm, L. Mechanisms of metal ion transfer into room-temperature ionic liquids: The role of anion exchange. J. Am. Chem. Soc. 2003, 125, 15466.

(25) Stepinski, D. C.; Jensen, M. P.; Dzielawa, J. A.; Dietz, M. L. Synergistic effects in the facilitated transfer of metal ions into room-temperature ionic liquids. Green Chem. 2005, 7, 151. 
(26) Ouadi, A.; Gadenne, B.; Hesemann, P.; Moreau, J. J. E.; Billard, I.; Gaillard, C.; Mekki, S.; Moutiers, G. Task-specific ionic liquids bearing 2-hydroxybenzylamine units: Synthesis and americium-extraction studies. Chem. Europ. J. 2006, 12, 3074.

(27) Visser, A. E.; Swatloski, R. P.; Reichert, W. M.; Mayton, R.; Sheff, S.; Wierzbicki, A.; Davis, J. H.; Rogers, R. D. Task-specific ionic liquids for the extraction of metal ions from aqueous solutions. Chem. Commun. 2001, 1, 135.

(28) Visser, A. E.; Swatloski, R. P.; Reichert, W. M.; Mayton, R.; Sheff, S.; Wierzbicki, A.; Davis, J. H.; Rogers, R. D. Task-specific ionic liquids incorporating novel cations for the coordination and extraction of $\mathrm{Hg}^{2+}$ and $\mathrm{Cd}^{2+}$ : Synthesis, characterization, and extraction studies. Environmen. Sci. Tech. 2002, 36, 2523.

(29) Bonhote, P.; Dias, A-P.; Papageorgiou, N.; Kalyanasundaram, K.; Graetzel, M. Hydrophobic, highly conductive ambient-temperature molten salts. Inorg. Chem. 1996, 35, $1168-1178$

(30) Holbrey J. D.; Seddon K. R. The phase behavior of 1-alkyl-3-methylimidazolium tetrafluoroborates; ionic liquids and ionic liquid crystals. J. Chem. Soc., Dalton Trans. 1999, $13,2133$.

(31) Huddleston, J. G.; Visser, A. E.; Reichert, W. M.; Willauer, H. D.; Broker, G. A.; Rogers, R. D. Characterization and comparison of hydrophilic and hydrophobic room temperature ionic liquids incorporating the imidazolium cation. Green Chem. 2001, 4, 156.

(32) Tokuda, H.; Hayamizu, K.; Ishii, K.; Susan, Md. A. B. H.; Watanabe M. Physicochemical properties and structures of room temperature ionic liquids. 1. Variation of Anionic Species. J. Phys. Chem. B 2004, 108, 16595. 
(33) Tokuda, H.; Hayamizu, K.; Ishii, K.; Susan, Md. A. B. H.; Watanabe, M. Physicochemical properties and structures of room temperature ionic liquids. 2. Variation of the alkyl chain length in imidazolium cations. J. Phys. Chem. B 2005, 109, 6103.

(34) Fitchett, B. D.; Knepp, T. N.; Conboy, J. C. 1-Alkyl-3-methylimidazolium bis(perfluoroalkylsulfonyl)imide water-immiscible ionic liquids J. Electrochem. Soc. 2004, $151, \mathrm{E} 219$.

(35) Fredlake, C. P.; Crosthwaite, J. M.; Hert, D. G.; Aki, S. N. V. K.; Brennecke, J. F. Thermophysical properties of imidazolium-based ionic liquids. J. Chem. Eng. Data 2004, 49, 954.

(36) Crosthwaite, J. M.; Muldoon, M. J.; Dixon, J. K.; Anderson, J. L.; Brennecke, J. F. Phase transition and decomposition temperatures, heat capacities and viscosities of pyridinium ionic liquids. J. Chem. Therm. 2005, 37, 559.

(37) MacFarlane, D. R.; Golding, J.; Forsyth, S.; Forsyth, M.; Deacon, G. B. Low viscosity ionic liquids based on organic salts of the dicyanamide anion. Chem. Comm. 2001, 16, 1430.

(38) Harris K. R.; Kanakubo M.; Woolf L. A. Temperature and Pressure Dependence of the Viscosity of the Ionic Liquids 1-Methyl-3-octylimidazolium Hexafluorophosphate and 1Methyl-3-octylimidazolium Tetrafluoroborate. J. Chem. Eng. Data, 2006, 51, 1161.

(39) Papaiconomou, N.; Yakelis, N.; Salminen, J.; Bergman, R.; Prausnitz, J. M., Synthesis and properties of seven ionic liquids containing 1-methyl-3-octylimidazolium or 1-butyl-4methylpyridinium cations. J. Chem Eng. Data 2006, 51, 1389.

(40) Papaiconomou, N.; Salminen, J.; Lee J-M.; Prausnitz, J. M. Physicochemical properties of hydrophobic ionic liquids containing 1-octylpyridinium, 1-octyl-2- 
methylpyridinium or 1-octyl-4-methylpyridinium cations. J. Chem. Eng. Data, published, March 8, 2007.

(41) Salminen J., Papaiconomou N., Lee J-M., Ramasubramanian A., Prausnitz J. M., and Newman J. Physico-chemical properties and toxicity of selected piperidinium and pyrrolidinium ionic liquids, to be published, 2007.

(42) Swatloski, R. P.; Holbrey, J. D.; Rogers, R. D. Ionic liquids are not always green: hydrolysis of 1-butyl-3-methylimidazolium hexafluorophosphate. Green Chem. 2003, 5, 361.

(43) Matsumoto, M.; Mochiduki, K.; Kondo, K. Toxicity of ionic liquids and organic solvents to lactic acid-producing bacteria. J. Biosci. Bioeng. 2004, 98, 344.

(44) Latala, A.; Stepnowski, P.; Nedzi, M.; Mrozik, W. Marine toxicity assessment of imidazolium ionic liquids: Acute effects on the Baltic algae Oocystis submarina and Cyclotella meneghiniana. Aquatic Toxicol. 2005, 73, 91.

(45) Stepnowski, P.; Skladanowski, A. C.; Ludwiczak, A.; Laczynska, E. Evaluating the cytotoxicity of ionic liquids using human cell line HeLa. Human Exp. Toxicol. 2004, 23, 513.

(46) Docherty, K. M.; Kulpa, C. F. Toxicity and antimicrobial activity of imidazolium and pyridinium ionic liquids. Green Chem. 2005, 7,185.

(47) Clark, P. D.; Mesher, S. T. E.; Primak, A. Phosphorus, Sulfur, and Silicon, 1996, 114, 99.

(48) Zhao, D.; Fei, Z.; Geldbach, T. J.; Scopelliti, R.; Dyson P. J. Nitrile-Functionalized Pyridinium Ionic Liquids: Synthesis, Characterization, and Their Application in CarbonCarbon Coupling Reactions. J. Am. Chem. Soc. 2004, 126, 15876. 
<smiles></smiles>

1-octyl-3methylimidazolium cation [OMIM] ${ }^{+}$<smiles>CCCCCCCC[n+]1ccc(C)cc1</smiles>

1-octyl-4-methylpyridinium cation [4MOPYR $]^{+}$<smiles></smiles>

1-octyl-3-methylpyridinium cation [3MOPYR $]^{+}$

$$
\stackrel{\mathrm{F}-\mathrm{B}}{\mathrm{B}}-\mathrm{F}
$$

tetrafluoroborate anion $\left[\mathrm{BF}_{4}\right]^{-}$

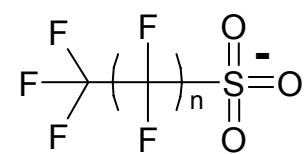

$\mathrm{n}=0$ triflate anion [TfO] $\mathrm{n}=3$ nonaflate anion $\mathrm{HfO}^{-}$

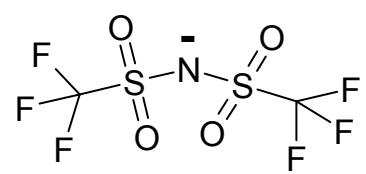

bis(trifluoromethylsulfonyl)imide anion $\left[\mathrm{Tf}_{2} \mathrm{~N}\right]$<smiles>Cc1cc[n+](CCCC#N)cc1</smiles>

1-butyronitrile-4-methylpyridinium cation [4MPYRCN] ${ }^{+}$<smiles>CN1CCCCC1</smiles>

1-butyronitrile-1-methylpiperidinium cation [MPIPCN]+<smiles>CSCC(CCCC[N+]1(C)CCCCC1)SC</smiles>

1-methyl-1-[4,5-bis(methylsulfide)]pentylpiperidinium cation [MPIPS $]_{2}{ }^{+}$<smiles>CSCC(CCCC[N+]1(C)CCCC1)SC</smiles>

1-methyl-1-[4,5-bis(methylsulfide)]pentylpyrrolidinium cation [MPYRROS $\left.]_{2}\right]^{+}$

Figure 1- Structures of cations and anions used in this work. 
Table 1- Ionic liquids and cations in water studied here at $\mathrm{pH} 7$ and $25^{\circ} \mathrm{C}$

\begin{tabular}{|c|c|}
\hline Extracting phase & Metal ions dissolved in water \\
\hline $\begin{array}{l}{\left[\mathrm{OMIM}^{+}\left[\mathrm{BF}_{4}\right]^{-}\right.} \\
{[3 \mathrm{MOPYR}]^{+}\left[\mathrm{BF}_{4}\right]^{-}} \\
{[4 \mathrm{MOPYR}]^{+}\left[\mathrm{BF}_{4}\right]^{-}}\end{array}$ & $\mathrm{Na}^{+}, \mathrm{K}^{+}, \mathrm{Cs}^{+}, \mathrm{Zn}^{2+}, \mathrm{Cd}^{2+}, \mathrm{Hg}^{2+}, \mathrm{Pb}^{2+}$ \\
\hline $\begin{array}{l}{\left[4 \mathrm{MOPYR}^{+}\left[\mathrm{Tf}_{2} \mathrm{~N}\right]^{-}\right.} \\
{[4 \mathrm{MOPYR}]^{+}[\mathrm{TfO}]^{-}} \\
{[4 \mathrm{MOPYR}]^{+}[\mathrm{NfO}]^{-}}\end{array}$ & $\begin{array}{l}\mathrm{Na}^{+}, \mathrm{Mg}^{2+}, \mathrm{Fe}^{3+}, \mathrm{Co}^{2+}, \mathrm{Ni}^{2+}, \mathrm{Cu}^{2+}, \mathrm{Zn}^{2+}, \\
\mathrm{Cd}^{2+}, \mathrm{Hg}^{2+}, \mathrm{Tl}^{+}, \mathrm{Pb}^{2+}, \mathrm{Sn}^{4+}, \mathrm{Ba}^{2+}\end{array}$ \\
\hline $\begin{array}{l}{[4 \mathrm{MPYRCN}]^{+}\left[\mathrm{Tf}_{2} \mathrm{~N}\right]^{-}} \\
{[\mathrm{MPIPCN}]^{+}\left[\mathrm{Tf}_{2} \mathrm{~N}\right]^{-}}\end{array}$ & $\begin{array}{l}\mathrm{Na}^{+}, \mathrm{Mg}^{2+}, \mathrm{Fe}^{3+}, \mathrm{Co}^{2+}, \mathrm{Ni}^{2+}, \mathrm{Cu}^{2+}, \mathrm{Zn}^{2+}, \\
\mathrm{Cd}^{2+}, \mathrm{Hg}^{2+}, \mathrm{Tl}^{+}, \mathrm{Pb}^{2+}, \mathrm{Sn}^{4+}, \mathrm{Ag}^{+}, \mathrm{Pd}^{2+} \text { b }\end{array}$ \\
\hline $\begin{array}{l}{\left[\mathrm{MPYRROS}_{2}\right]^{+}\left[\mathrm{Tf}_{2} \mathrm{~N}\right]^{-}} \\
{\left[\mathrm{MPIPS}_{2}\right]^{+}\left[\mathrm{Tf}_{2} \mathrm{~N}^{-}\right.}\end{array}$ & $\begin{array}{l}\mathrm{Na}^{+}, \mathrm{K}^{+}, \mathrm{Mg}^{2+}, \mathrm{Fe}^{3+}, \mathrm{Co}^{2+}, \mathrm{Ni}^{2+}, \mathrm{Cu}^{2+}, \\
\mathrm{Zn}^{2+}, \mathrm{Cd}^{2+}, \mathrm{Hg}^{2+}, \mathrm{Tl}^{+}, \mathrm{Pb}^{2+}, \mathrm{Sn}^{4+}, \mathrm{Ba}^{2+}\end{array}$ \\
\hline
\end{tabular}

a: Silver nitrate was extracted separately. b: Palladium chloride was extracted separately.

Table 2- Distribution coefficients $D$ for cations in water extracted with $[\mathrm{OMIM}]^{+}\left[\mathrm{BF}_{4}\right]^{-}$, $[3 \mathrm{MOPYR}]^{+}\left[\mathrm{BF}_{4}\right]^{-}$and $[4 \mathrm{MOPYR}]^{+}\left[\mathrm{BF}_{4}\right]^{-}$at $\mathrm{pH} 7$ and $25^{\circ} \mathrm{C}$.

\begin{tabular}{|l|l|l|l|}
\hline & {$[\mathrm{OMIM}]^{+}\left[\mathrm{BF}_{4}\right]^{-}$} & {$\left[3 \mathrm{MOPYR}^{+}\left[\mathrm{BF}_{4}\right]^{-}\right.$} & {$[4 \mathrm{MOPYR}]^{+}\left[\mathrm{BF}_{4}\right]^{-}$} \\
\hline $\mathrm{Na}^{+}$ & 0.03 & $\mathrm{a}$ & $\mathrm{a}$ \\
\hline $\mathrm{K}^{+}$ & 0.06 & 0.05 & $\mathrm{a}$ \\
\hline $\mathrm{Cs}^{+}$ & 0.15 & $\mathrm{a}$ & $\mathrm{a}$ \\
\hline $\mathrm{Zn}^{2+}$ & 0.03 & 0.17 & 0.23 \\
\hline $\mathrm{Cd}^{2+}$ & 0.04 & 0.31 & 1.71 \\
\hline $\mathrm{Hg}^{2+}$ & 24.9 & 1000 & 1000 \\
\hline $\mathrm{Pb}^{2+}$ & 11.9 & 11.0 & 8.66 \\
\hline
\end{tabular}

${ }^{\mathrm{a}}$ : no extraction observed, $\mathrm{D}$ is below 0.05 . 
Table 3- Distribution coefficients $D$ for cations in water extracted with $[4 \mathrm{MOPYR}]^{+}\left[\mathrm{Tf}_{2} \mathrm{~N}\right]^{-}$, $[4 \mathrm{MOPYR}]^{+}[\mathrm{TfO}]^{-}$, or $[4 \mathrm{MOPYR}]^{+}[\mathrm{NfO}]^{-}$at $\mathrm{pH} 7$ and $25^{\circ} \mathrm{C}$.

\begin{tabular}{|l|l|l|l|}
\hline & {$[4 \mathrm{MOPYR}]^{+}\left[\mathrm{Tf}_{2} \mathrm{~N}\right]^{-}$} & {$[4 \mathrm{MOPYR}]^{+}[\mathrm{TfO}]^{-}$} & {$[4 \mathrm{MOPYR}]^{+}[\mathrm{NfO}]^{-}$} \\
\hline $\mathrm{Na}^{+}$ & a & a & 0.54 \\
\hline $\mathrm{Cu}^{2+}$ & a & 0.13 & a \\
\hline $\mathrm{Tl}^{+}$ & a & 0.50 & a \\
\hline $\mathrm{Hg}^{2+}$ & 0.22 & 1000 & 1000 \\
\hline
\end{tabular}

${ }^{\mathrm{a}}$ : no extraction observed. $D$ is below 0.05 .

Table 4- Distribution coefficients $D$ for cations in water extracted with [4MPYRCN $]^{+}\left[\mathrm{Tf}_{2} \mathrm{~N}\right]^{-}$ or $[\mathrm{MPIPCN}]^{+}\left[\mathrm{Tf}_{2} \mathrm{~N}\right]^{-}$at $\mathrm{pH} 7$ and $25^{\circ} \mathrm{C}$.

\begin{tabular}{|l|l|l|}
\hline & {$[4 \mathrm{MPYRCN}]^{+}\left[\mathrm{Tf}_{2} \mathrm{~N}^{-}\right.$} & {$[\mathrm{MPIPCN}]^{+}\left[\mathrm{Tf}_{2} \mathrm{~N}\right]^{-}$} \\
\hline $\mathrm{Na}^{+}$ & 1.26 & 0.05 \\
\hline $\mathrm{Mg}^{2+}$ & 0.68 & 0.06 \\
\hline $\mathrm{Fe}^{3+}$ & 0.98 & $\mathrm{a}$ \\
\hline $\mathrm{Co}^{2+}$ & 0.54 & $\mathrm{a}$ \\
\hline $\mathrm{Ni}^{2+}$ & 0.53 & $\mathrm{a}$ \\
\hline $\mathrm{Cu}^{2+}$ & 0.83 & $\mathrm{a}$ \\
\hline $\mathrm{Zn}^{2+}$ & 0.33 & $\mathrm{a}$ \\
\hline $\mathrm{Cd}^{2+}$ & 0.39 & 0.11 \\
\hline $\mathrm{Hg}^{2+}$ & 0.47 & 0.23 \\
\hline $\mathrm{Tl}^{+}$ & 1.7 & $\mathrm{a}$ \\
\hline $\mathrm{Pb}^{2+}$ & 0.64 & 0.11 \\
\hline $\mathrm{Sn}^{4+}$ & 1.36 & \\
\hline
\end{tabular}

a: no extraction observed. $D$ is below 0.05 . 
Table 5- Distribution coefficients $D$ for silver and palladium in water extracted with $[4 \mathrm{MPYRCN}]^{+}\left[\mathrm{Tf}_{2} \mathrm{~N}\right]^{-}$or $[\mathrm{MPIPCN}]^{+}\left[\mathrm{Tf}_{2} \mathrm{~N}\right]^{-}$at $\mathrm{pH} 7$ and $25^{\circ} \mathrm{C}$. Each metal ion was extracted separately. Silver nitrate salt and potassium palladium chloride were used.

\begin{tabular}{|l|l|l|}
\hline & {$\left[4 \mathrm{MPYRCN}^{+}\left[\mathrm{Tf}_{2} \mathrm{~N}\right]^{-}\right.$} & {$[\mathrm{MPIPCN}]^{+}\left[\mathrm{Tf}_{2} \mathrm{~N}\right]^{-}$} \\
\hline $\mathrm{Ag}^{+}$ & 41 & 8.1 \\
\hline $\mathrm{Pd}^{2+}$ & 1000 & 1000 \\
\hline
\end{tabular}

Table 6- Distribution coefficients $D$ for metal ions in water extracted with $\left[\mathrm{MPYRROS}_{2}\right]^{+}\left[\mathrm{Tf}_{2} \mathrm{~N}\right]^{-}$or $\left[\mathrm{MPIPS}_{2}\right]^{+}\left[\mathrm{Tf}_{2} \mathrm{~N}\right]^{-}$at $\mathrm{pH} 7$ and $25^{\circ} \mathrm{C}$.

\begin{tabular}{|l|l|l|}
\hline & {$\left[\mathrm{MPYRROS}_{2}\right]^{+}\left[\mathrm{Tf}_{2} \mathrm{~N}\right]^{-}$} & {$\left[\mathrm{MPIPS}_{2}\right]^{+}\left[\mathrm{Tf}_{2} \mathrm{~N}\right]^{-}$} \\
\hline $\mathrm{Na}^{+}$ & 0.41 & $\mathrm{a}$ \\
\hline $\mathrm{K}^{+}$ & 0.46 & $\mathrm{a}$ \\
\hline $\mathrm{Mg}^{2+}$ & 0.37 & $\mathrm{a}$ \\
\hline $\mathrm{Fe}^{3+}$ & 2.89 & 0.11 \\
\hline $\mathrm{Co}^{2+}$ & 0.20 & $\mathrm{a}$ \\
\hline $\mathrm{Ni}^{2+}$ & 0.19 & 1000 \\
\hline $\mathrm{Cu}^{2+}$ & 1000 & $\mathrm{a}$ \\
\hline $\mathrm{Zn}^{2+}$ & 0.85 & 0.17 \\
\hline $\mathrm{Cd}^{2+}$ & 0.97 & 1000 \\
\hline $\mathrm{Hg}^{2+}$ & 1000 & $\mathrm{a}$ \\
\hline $\mathrm{Tl}^{+}$ & 0.68 & $\mathrm{a}$ \\
\hline $\mathrm{Pb}^{2+}$ & 0.23 & 70.5 \\
\hline $\mathrm{Sn}^{4+}$ & 4.35 & $\mathrm{a}$ \\
\hline $\mathrm{Ba}^{2+}$ & 0.14 & \\
\hline
\end{tabular}

a. no extraction observed. $D$ is below 0.05 . 